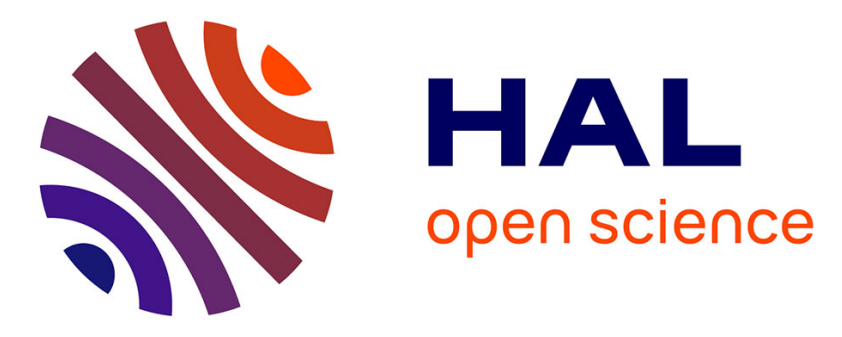

\title{
Solidification sequence and four-phase eutectic in AlSi6Cu4Fe2 alloy
}

\author{
Djar Oquab, Claudie Josse, Arnaud Proietti, Alessandro Pugliara, Jacques \\ Lacaze, Sonja Steinbach, Deni Ferdian, Bernard Viguier
}

\section{- To cite this version:}

Djar Oquab, Claudie Josse, Arnaud Proietti, Alessandro Pugliara, Jacques Lacaze, et al.. Solidification sequence and four-phase eutectic in AlSi6Cu4Fe2 alloy. Materials Characterization, 2019, 156, pp.109846. 10.1016/j.matchar.2019.109846 . hal-02458622

\section{HAL Id: hal-02458622 \\ https://hal.science/hal-02458622}

Submitted on 28 Jan 2020

HAL is a multi-disciplinary open access archive for the deposit and dissemination of scientific research documents, whether they are published or not. The documents may come from teaching and research institutions in France or abroad, or from public or private research centers.
L'archive ouverte pluridisciplinaire HAL, est destinée au dépôt et à la diffusion de documents scientifiques de niveau recherche, publiés ou non, émanant des établissements d'enseignement et de recherche français ou étrangers, des laboratoires publics ou privés. 


\section{OATAO \\ Open Archive Toulouse Archive Ouverte}

\section{Open Archive Toulouse Archive Ouverte (OATAO)}

OATAO is an open access repository that collects the work of Toulouse researchers and makes it freely available over the web where possible

This is an author's version published in: http://oatao.univ-toulouse.fr/25346

Official URL: https://doi.org/10.1016/j.matchar.2019.109846

\section{To cite this version:}

Oquab, Djar Alessandro Deni and Viguier, Bernard 5 Solidification sequence and four-phase eutectic in AlSi6Cu4Fe2 alloy. (2019) Materials Characterization, 156. 109846. ISSN 1044-5803

Any correspondence concerning this service should be sent to the repository administrator: tech-oatao@listes-diff.inp-toulouse.fr 


\title{
Solidification sequence and four-phase eutectic in AlSi6Cu4Fe2 alloy
}

\author{
Djar Oquab $^{\mathrm{a}}$, Claudie Josse ${ }^{\mathrm{b}}$, Arnaud Proietti ${ }^{\mathrm{b}}$, Alessandro Pugliara ${ }^{\mathrm{a}}$, Jacques Lacaze $^{\mathrm{a}, *}$, \\ Sonja Steinbach ${ }^{c}$, Deni Ferdian ${ }^{\mathrm{d}}$, Bernard Viguier ${ }^{\mathrm{a}}$ \\ " CIRMAT; Universite de Toulouse, ENSIACET, BP 44362, 31030 Toulouse, Cedex 4, Prance

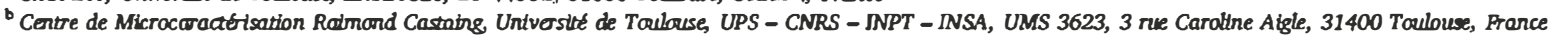 \\ 'Insitur für Materlalphysik in Weltraum, Deutsches Zentrum für Luft und Raunfahrt (DLR), 51170 Köbn, Germary \\ ¿ Dept of Mealhugy and Maverials Engtneering, Universtens Indanesia, Kanqus Ban UI Depok, 16424, Indonesia
}

\section{A RT I CLE INFO}

Keywards:

Pour-phase eutectic

Regular eutectic

Rosette

Aluminium alloy

\begin{abstract}
A B S T R A C T
Differential thermal analyses of an AlSi6Cu4Fe2 alloy at various cooling rates from the liquid state were performed which showed: i) possible discrepancies in the first solidification steps and; ii) solidification ending with multiple peaks at low cooling rate. Metallographic observation of the samples gave hint for understanding the discrepancies while the presence of rounded multi-phase pools - or so-called rosettes - en trapped within dendrite arms explained the multiple peaks because they solidified independently of each other.

The very fine eutectic microstructure in these rosettes was investigated by scanning electron microscopy which showed the precipitation of a four-phase eutectic. Focused ions beam milling was then used to investigate the topology of the distribution of the four phases. Electron backscattered diffraction analysis was carried out to investigate their local crystallographic orientations and transmission electron microscopy analysis was performed to identify the very fine crystalline structures. This eutectic appears as one of the very few regular fourphase eutectics reported in the literature.
\end{abstract}

\section{Introduction}

$\mathrm{Al} \mathrm{Cu} \mathrm{Si} \mathrm{alloys} \mathrm{are} \mathrm{the} \mathrm{base} \mathrm{of} \mathrm{foundry} \mathrm{alloys} \mathrm{of} \mathrm{interest} \mathrm{because} \mathrm{of}$ being heat treatable and having good corrosion resistance. For die casting these alloys are however complemented with a low amount of iron to limit sticking of the melt to the die, and they contain also some manganese to avoid the formation of the most detrimental Fe bearing phases. As part of an extended study devoted to the effect of fluid flow on the microstructure and defect formation in $\mathrm{Al}$ alloys, synthetic AlSi6Cu 4 alloys with $0.5,1$ and 2 added Fe (all in wt\%) were in vestigated (model for A319 alloy family) [1].

According to literature [2 4], solidification of aluminium alloys in the $\mathrm{Al} \mathrm{CuSi} \mathrm{Fe} \mathrm{system} \mathrm{may} \mathrm{involve} \mathrm{precipitation} \mathrm{of} \mathrm{Al}_{3} \mathrm{Fe}, \mathrm{Al}_{6} \mathrm{Fe}$, $\mathrm{Al}_{7} \mathrm{Cu}_{2} \mathrm{Fe}, \alpha \mathrm{Al}_{8} \mathrm{Fe}_{2} \mathrm{Si}, \beta \mathrm{Al}_{9} \mathrm{Fe}_{2} \mathrm{Si}_{2}, \theta \mathrm{Al}_{2} \mathrm{Cu}$ and $\mathrm{Si}$ in addition to the aluminium rich solid solution (Al). With the above contents in $\mathrm{Cu}, \mathrm{Si}$ and $\mathrm{Fe}$, the expected phases are in fact $\alpha, \beta, \mathrm{Al}_{2} \mathrm{Cu}, \mathrm{Si}$ and ( $\mathrm{Al}$ ). The aim of this work was to investigate how the cooling rate could affect pre cipitation of the minor phases, and it was chosen to work with a high enough Fe content so that the alloy would be hyper eutectic. Differ ential thermal analyses (DTA) were performed which showed: i) in consistencies in the first thermal arrests on cooling from the liquid state; and ii) solidification ending with multiple peaks at low cooling rates. These two features were more particularly studied by various microscopy techniques whose results are reported below.

\section{Experimental details}

The AlSi6Cu4Fe2 alloy was prepared from high purity materials provided by Hydro Aluminium Rolled Produc $\mathrm{GmbH}$, Bonn, Germany. The inductively coupled plasma optical emission spectrometry (ICP $\mathrm{OES}$ ) has been used for the determination of the alloying constituents: $5.93 \mathrm{Si}, 2.08 \mathrm{Fe}$ and $3.98 \mathrm{Cu}(\mathrm{wt} \%)$ and less than $50 \mathrm{ppm}$ of any other elements.

Differential thermal analysis experiments were performed with a SETSYS 16/18 apparatus from SETARAM, with alumina crucibles and alumina powder as inert reference. Samples were cylinders $3.9 \mathrm{~mm}$ in diameter and $5 \mathrm{~mm}$ in height. DTA records have been made upon cooling after melting at a rate of $10^{\circ} \mathrm{C} / \mathrm{min}$ up to a maximum tem perature of $650{ }^{\circ} \mathrm{C}$ or $700{ }^{\circ} \mathrm{C}$. The choice of the upper temperature de pended on the subsequent cooling rate, being $650^{\circ} \mathrm{C}$ when the cooling rate was lower than $3^{\circ} \mathrm{C} / \mathrm{min}$ and $700^{\circ} \mathrm{C}$ when higher. Six cooling rates were considered: $0.2,0.5,1,2,3$ and $5^{\circ} \mathrm{C} / \mathrm{min}$. The records were

\footnotetext{
* Corresponding author.

E-mail address: Jacques.lacaze@ensiacet.fr (J. Lacaze).
} 
uncorrected in any ways and particularly not for cooling rate effect. Calibration of the DTA cell at very low scanning rate indicated a maximum possible shift of $2{ }^{\circ} \mathrm{C}$ of the recorded temperatures.

After standard metallographic preparation, the samples were ob served by light optical microscopy (LOM) and scanning electron $\mathrm{mi}$ croscopy (SEM). A rosette was then selected that was submitted to se quential thinning with a focused ion beam (FIB, ThermoFischer Helios 600i) for 3D characterization using both SEM images and elements mapping by $\mathrm{X}$ ray energy dispersive spectrometry (EDS). Two other foils were prepared by FIB milling, one thin foil for characterizing the crystallography of the phases by transmission electron microscopy (TEM, JEOL JEM 2100F) and by scanning transmission electron mi croscopy (STEM), and another one to determine phases and grains or ientation distribution by electron backscattered diffraction (EBSD) analysis. EBSD was performed with a JEOL JSM 7100F with a working distance of $15 \mathrm{~mm}$, an accelerating voltage of $20 \mathrm{kV}$. EBSD was coupled with EDS to avoid confusion between Si precipitates and (Al). The pole figures presented in the Results section are oriented the same way as the corresponding images ( $\mathrm{X}$ and $\mathrm{Y}$ being respectively the horizontal and vertical directions in the plane of the image, and $\mathrm{Z}$ the normal to this plane).

\section{Results}

\subsection{DTA results}

In Fig. 1 are plotted the DTA records upon cooling at 2, 3 and $5{ }^{\circ} \mathrm{C}$ / min, which have been offset along the Y axis for clarity. They all show similar features characterized by three main peaks starting respectively at about $600{ }^{\circ} \mathrm{C}, 550{ }^{\circ} \mathrm{C}$ and $500{ }^{\circ} \mathrm{C}$ on the record at $2{ }^{\circ} \mathrm{C} / \mathrm{min}$. Note that the slope at the beginning of each of these three main peaks is such that it is ensured the corresponding reactions proceeded with some under cooling. In between the two first main peaks at higher temperatures, it is seen that one additional arrest shows up which is indicated with an open arrow. This sequence of thermal arrests may be compared to the solidification sequence predicted with the Scheil module of the Ther mocalc software [5] and using the TCAL2 database [6]:

1. Precipitation of $\alpha \mathrm{Al}_{8} \mathrm{Fe}_{2} \mathrm{Si}$ at $641.3^{\circ} \mathrm{C}$.

2. Appearance of (Al) at $608.6^{\circ} \mathrm{C}$ in an eutectic reaction with $\alpha$.

3. Appearance of $\beta \mathrm{Al}_{9} \mathrm{Fe}_{2} \mathrm{Si}_{2}$ at $603.4^{\circ} \mathrm{C}$ which replaces $\alpha$.

4. Appearance of $\mathrm{Si}$ as a three phase (Al) $\mathrm{Si} \beta$ eutectic at $559.6^{\circ} \mathrm{C}$.

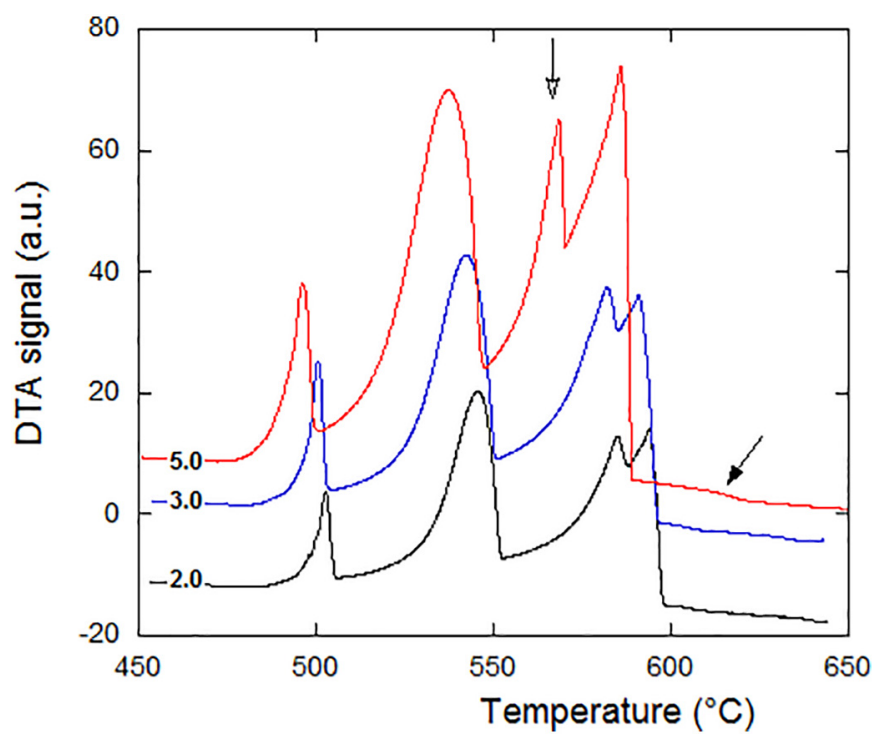

Fig. 1. DTA records upon cooling at 2,3 and $5{ }^{\circ} \mathrm{C} / \mathrm{min}$ as indicated on the curves.

\section{Final four phase (Al) $\mathrm{Si} \beta \mathrm{Al}_{2} \mathrm{Cu}$ eutectic at $521.6^{\circ} \mathrm{C}$.}

From the predicted amount of phases to precipitate at each of these reactions, the three main peaks are easily related to precipitation of (Al), $\mathrm{Si}$ and $\mathrm{Al}_{2} \mathrm{Cu}$, i.e. reactions 2,4 and 5 in the above listing, re spectively. Furthermore, the intermediate peak should correspond to precipitation of $\beta$. Also, a careful observation of Fig. 1 shows that the record at $5{ }^{\circ} \mathrm{C} / \mathrm{min}$ presents a shallow thermal arrest at about $620^{\circ} \mathrm{C}$ which could relate to primary precipitation of $\alpha$ (solid arrow in Fig. 1). Then, for this particular record, the intermediate peak could effectively be associated with $\beta$ precipitation. However, for the two other records, primary precipitation could not be evidenced leading to some un certainty on the nature of the intermediate peak.

Fig. 2 a shows the whole DTA records at cooling rates of $0.2,0.5$ and $1{ }^{\circ} \mathrm{C} / \mathrm{min}$ where the same three main peaks are observed. It is noticed again that no thermal arrest could be evidenced at temperature higher than that for the first main peak, i.e. above $600^{\circ} \mathrm{C}$. Also, the inter mediate peak does not appear similarly in these three curves. For 0.5 and $1.0^{\circ} \mathrm{C} / \mathrm{min}$, there is one intermediate arrest similar to those in Fig. 1, while at the lowest cooling rate two thermal arrests could be identified. Further understanding of the changes in the upper tem perature range of the records was gained by observing the micro structures, see later.

However, the most striking observation in Fig. $2 \mathrm{a}$ is that the third main thermal arrest starting at about $510{ }^{\circ} \mathrm{C}$ is not simple and consists in successive and short peaks. In the zoom of the DTA traces in Fig. 2 b, it is seen that the very last arrests may appear at a temperature lower than $500^{\circ} \mathrm{C}$, i.e. more than $10^{\circ} \mathrm{C}$ below the start of the final eutectic reaction, and more than $20^{\circ} \mathrm{C}$ below the equilibrium four phase eu tectic temperature. Similar multi stage eutectic solidification had been observed previously at the end of solidification of $\mathrm{Al} \mathrm{Cu} \mathrm{Mg} \mathrm{Si} \mathrm{alloys}$ where they could be related to independent crystallization of isolated pockets of liquid [7]. Because of the significant undercooling at which these pockets solidify, their microstructure was very fine and suggested to call them "rosettes". Similar features were observed during the present study as detailed below.

\subsection{Light optical observation of the samples microstructure}

The diametrical vertical sections of the six samples were observed and those for $0.5^{\circ} \mathrm{C} / \mathrm{min}$ and $5{ }^{\circ} \mathrm{C} / \mathrm{min}$ are presented in Fig. 3. One clearly sees the dendritic structure of the (Al) phase that becomes finer with increase in the cooling rate. Also, at the bottom of all six samples, a few large and blocky dark grey precipitates were observed which certainly precipitated before the development of the (Al) dendritic network, see Fig. 4 for an enlarged view. With increasing cooling rate, these precipitates become finer and could be observed also along the vertical surface of the samples as illustrated with the micrograph in Fig. $4 \mathrm{~b}$ for the sample cooled at $5{ }^{\circ} \mathrm{C} / \mathrm{min}$.

EDS measurements on the large precipitates confirmed they consist of $\alpha$ phase. Thus, the $\alpha$ phase was effectively the first phase to appear during cooling from the liquid, in contact with the crucible and either only at the bottom of the samples at low cooling rate or also along the vertical surface at higher cooling rate. As the amount of the $\alpha$ phase to precipitate is low, this arrest was clearly detected only at $5{ }^{\circ} \mathrm{C} / \mathrm{min}$. Further, the growth of the precipitates depleted progressively the melt in iron and it may well be that the liquid was not homogeneous when the network of (Al) dendrites formed. This may have led to changes in the conditions for $\beta$ nucleation explaining the discrepancies between the records, and in particular that the thermal arrest associated to this phase appeared at significantly lower temperature for the cooling rate of $0.2^{\circ} \mathrm{C} / \mathrm{min}$ than for the other cooling rates.

Finally, Fig. 5 illustrates the various minor phases that could be observed in the interdendritic areas of the bulk of all samples. $\beta$ pre cipitates appear as thin light grey platelets which are most often asso ciated with $\mathrm{Si}$ plates with dark grey contrast. $\mathrm{Al}_{2} \mathrm{Cu}$ appears as very 

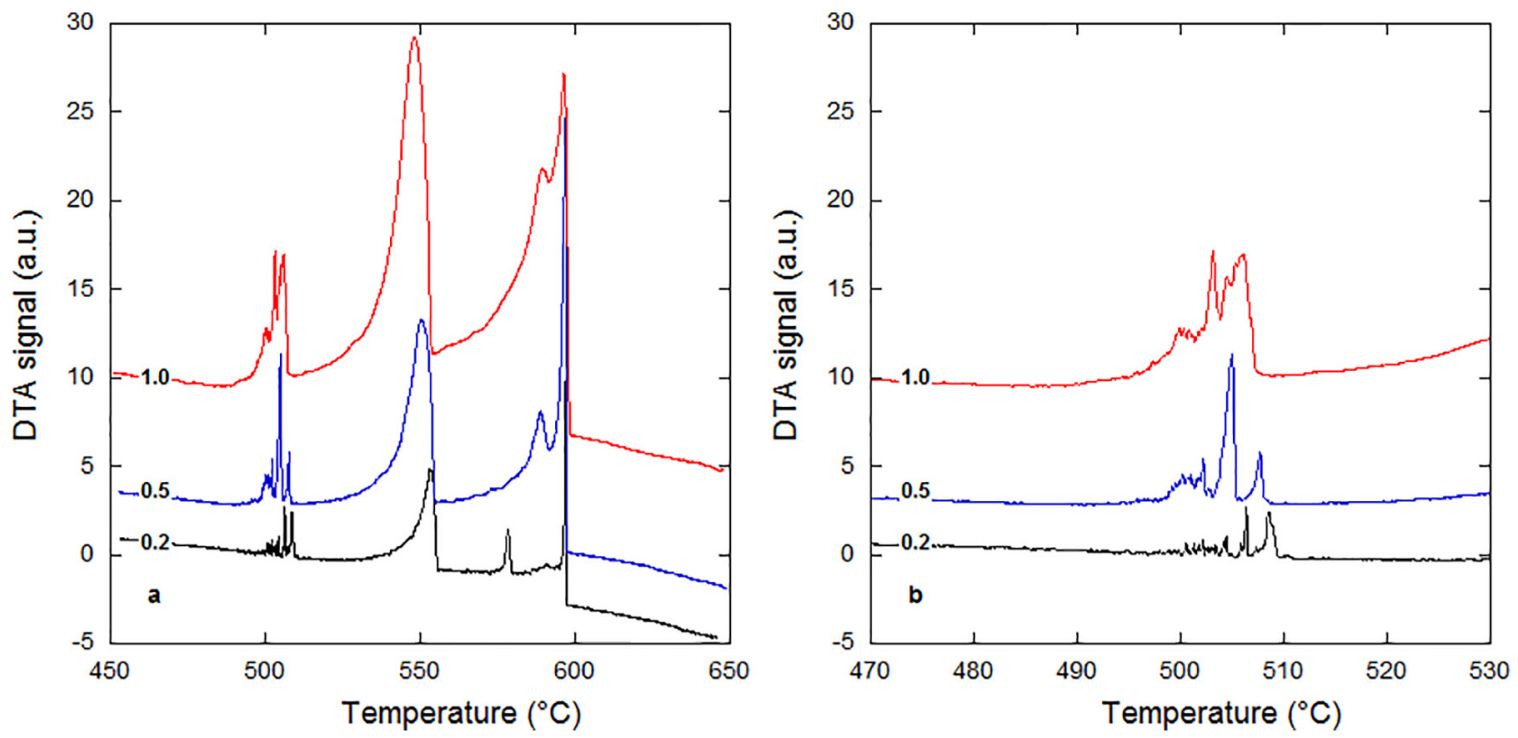

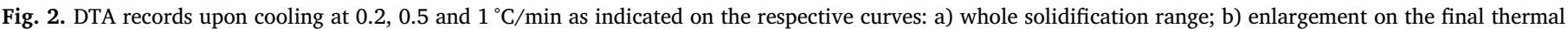
arrest.

light grey irregular and rounded precipitates while (Al) constitutes the background and has the brightest contrast. Note that the spatial and size distributions of the phases are inhomogeneous and irregular in these interdendritic areas.

In all samples, rounded areas with a very fine microstructure could be observed as illustrated in Fig. 6. In fact, contrary to previous report on a ternary $\mathrm{Al} \mathrm{Fe} \mathrm{Si} \mathrm{alloy} \mathrm{[8],} \mathrm{the} \mathrm{number} \mathrm{of} \mathrm{these} \mathrm{so} \mathrm{called} \mathrm{rosettes}$ was increasing as the cooling rate was decreased. Owing to the fineness of their microstructure, they were expected to have solidified with significant undercooling and, being isolated from each other, this must have happened independently and could well explain the sequence of small peaks at lowest temperatures in Fig. $2 \mathrm{~b}$. If this is the case, the microstructure of these rosettes should consist in a four phase eutectic and this was looked for by electron microscopy.

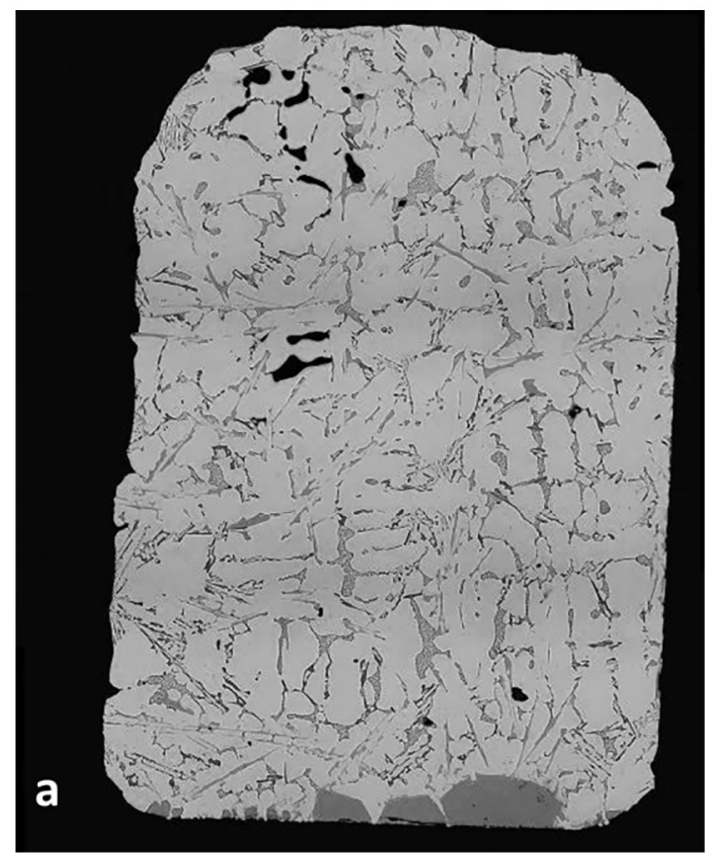

\subsection{Electron microscopy observation of the rosettes}

Fig. 7 shows a SEM micrograph of another rosette in the sample cooled at $0.2{ }^{\circ} \mathrm{C} / \mathrm{min}$ together with the corresponding EDS maps of $\mathrm{Si}$, $\mathrm{Cu}$ and Fe. The various FIB sections prepared for the present work are located on the SEM image (Fig. 7 a). The microstructure of the rosette appears as a fine intermix of ( $\mathrm{Al})$ in dark grey contrast and $\mathrm{Al}_{2} \mathrm{Cu}$ in bright contrast as also evidenced with the $\mathrm{Cu}$ map in Fig. $7 \mathrm{c}$. The si licon map in Fig. 7 b shows clear Si precipitates which are nearly evenly distributed in the rosette, with only a slightly higher amount at the periphery. From the iron map in Fig. 7 d, one could imagine there are also Fe bearing precipitates but this should be ascertained by closer investigation.

TEM and EBSD analyses as well as a 3D reconstruction have been carried out on the areas indicated in Fig. 7 a. Fig. 8 presents images of the $3 \mathrm{D}$ reconstruction as obtained by stacking EDS maps recorded

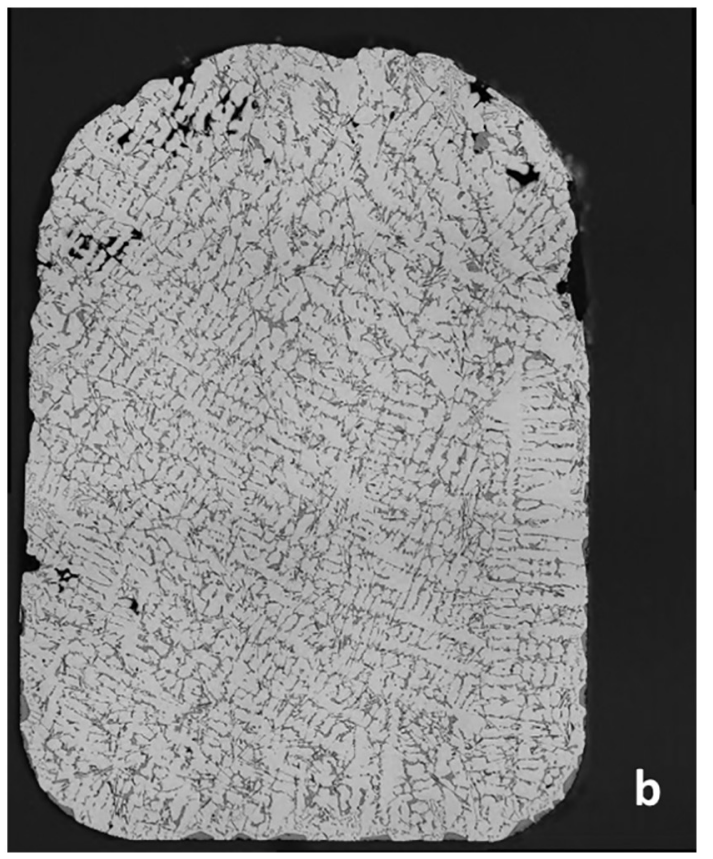

Fig. 3. Mosaic image of LOM micrographs of the samples cooled at $0.5^{\circ} \mathrm{C} / \mathrm{min}$ (a) and $5{ }^{\circ} \mathrm{C} / \mathrm{min}$ (b). The width of the sample section is $3.9 \mathrm{~mm}$. 

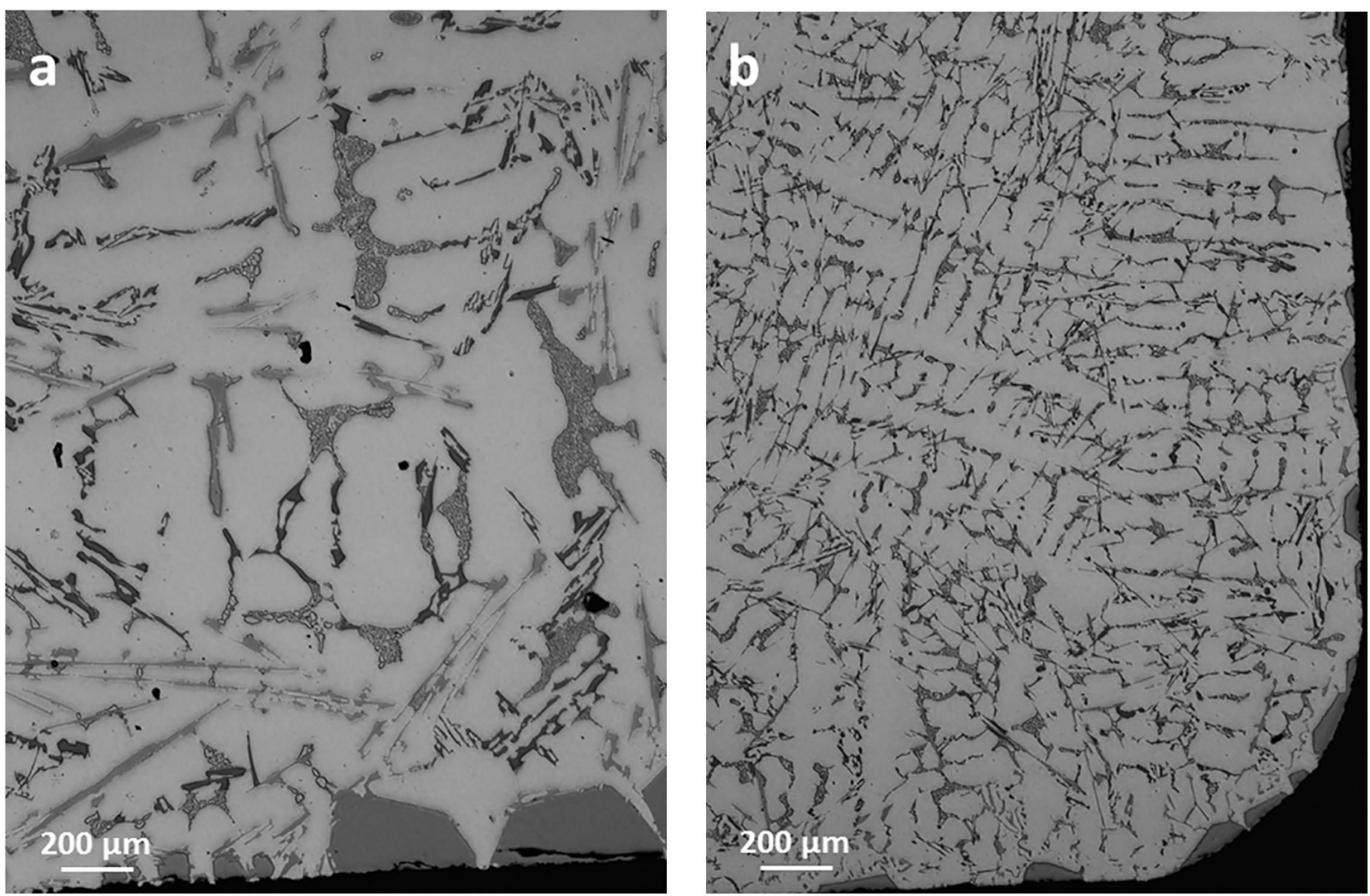

Fig. 4. LOM micrographs of the samples cooled at $0.5^{\circ} \mathrm{C} / \mathrm{min}$ (a) and $5{ }^{\circ} \mathrm{C} / \mathrm{min}$ (b).

during FIB milling. Here are presented 3D maps of the areas rich in silicon (a) and in iron (b). It is noteworthy that the silicon particles seem disconnected while both $(\mathrm{Al})$ and $\mathrm{Al}_{2} \mathrm{Cu}$ were found to be each interconnected, as well as being entangled. In a previous study on three phase rosettes in an $\mathrm{Al} \mathrm{Fe} \mathrm{Si} \mathrm{alloy,} \mathrm{both} \mathrm{(} \mathrm{Al}$ ) and $\mathrm{Si}$ were connected and entangled while short $\beta$ plates were unevenly distributed and dis connected from each other [9]. It is quite interesting to notice that the predicted fraction of $\mathrm{Si}$ is nearly the same, about $10 \%$, in the three phase eutectic of the ternary $\mathrm{Al} \mathrm{Fe} \mathrm{Si} \mathrm{system} \mathrm{and} \mathrm{in} \mathrm{the} \mathrm{four} \mathrm{phase}$ eutectic of the $\mathrm{Al} \mathrm{Cu} \mathrm{Fe}$ Si system.

From Fig. 8 b, it may be guessed that the Fe rich phase appears also as plates in the rosette of the quaternary alloy, though shorter than in interdendritic areas (Fig. 5). To verify which phase it consists of, a thin foil was ion milled out from the same rosette and thin plates were ef fectively observed and characterized by TEM as illustrated with Fig. 9 a and $\mathrm{b}$. This phase was analysed by EDS and by selected area electron diffraction (SAED) on the area defined with a circle in Fig. 9 b. The EDS analysis confirmed that it is rich in iron and, as expected, the experi mental SAED (Fig. 9 c) could be indexed as $\beta$ phase with an error less than $10 \%$. This indexation (Fig. $9 \mathrm{~d}$ ) was carried out comparing the

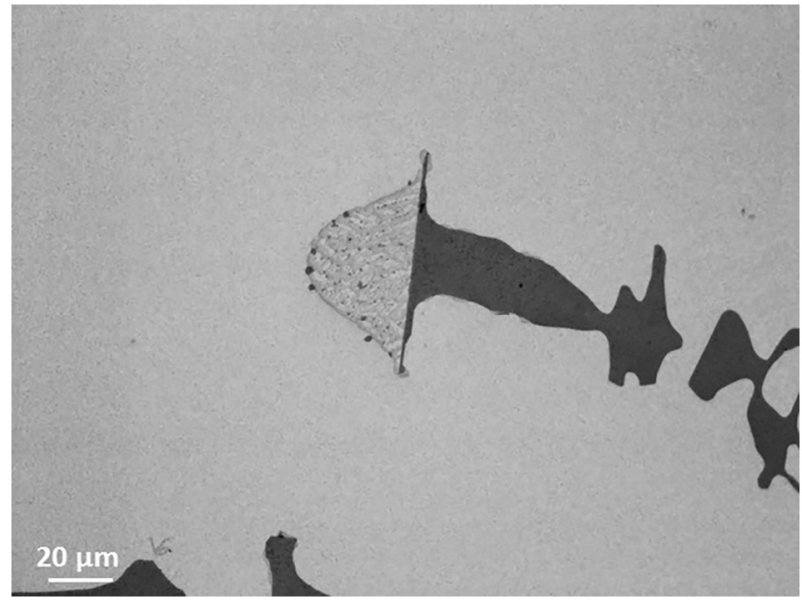

Fig. 6. LOM micrograph of the samples cooled at $0.2^{\circ} \mathrm{C} / \mathrm{min}$.
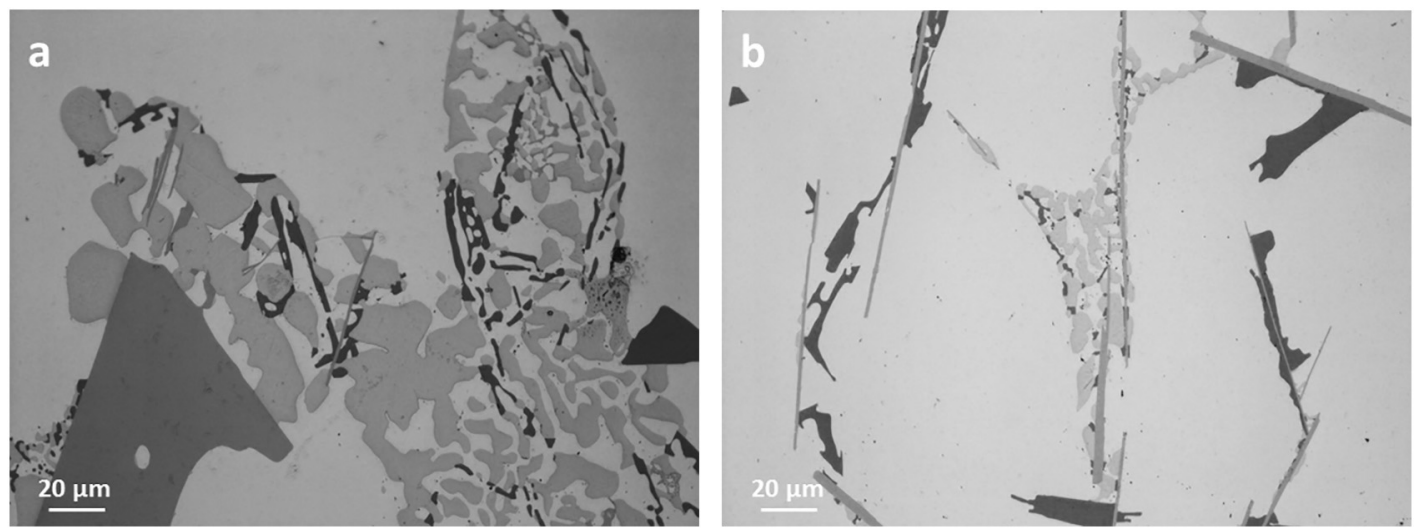

Fig. 5. LOM micrographs of the samples cooled at $0.5^{\circ} \mathrm{C} / \mathrm{min}$ (a) and $5^{\circ} \mathrm{C} / \mathrm{min}$ (b). 


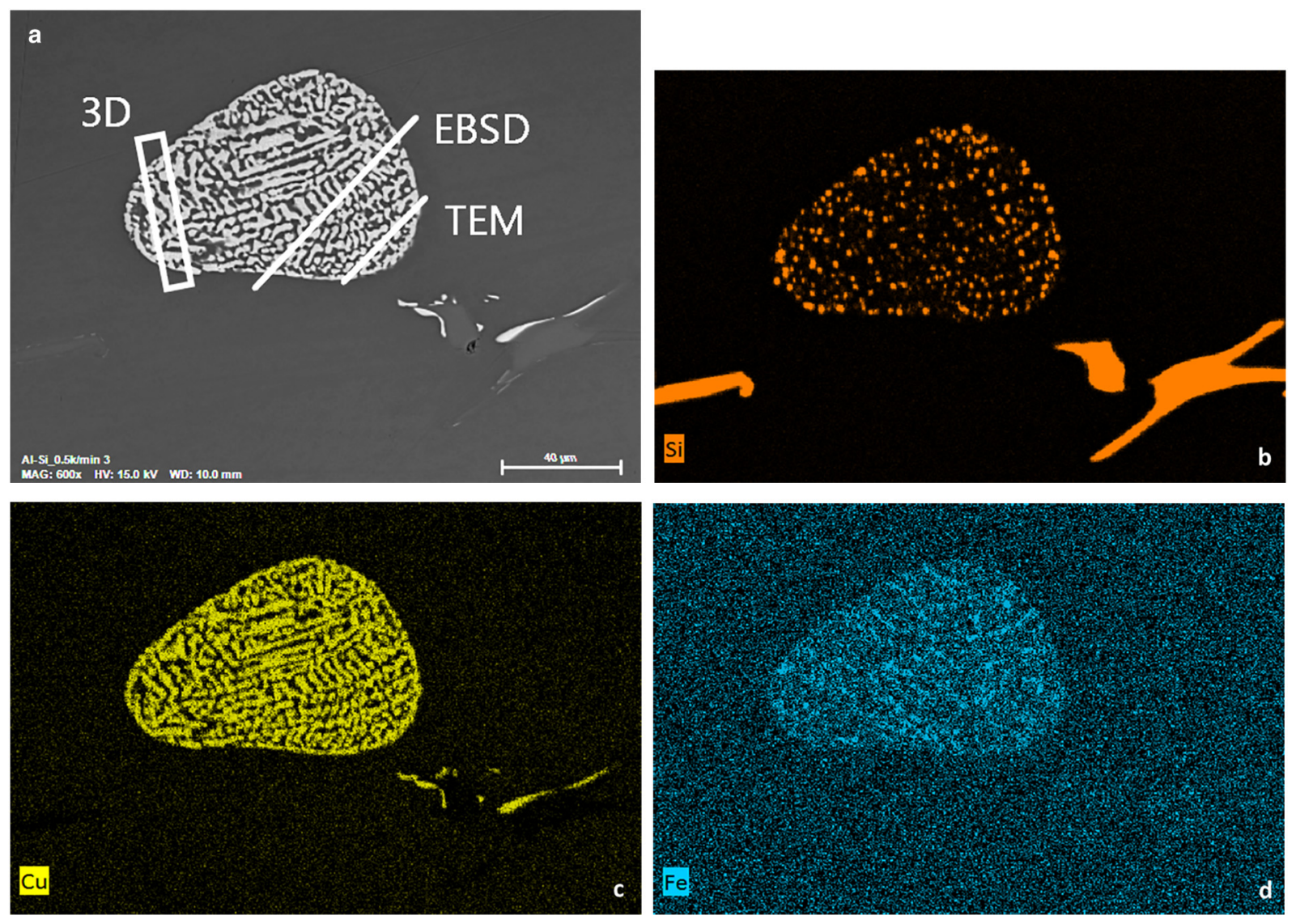

Fig. 7. Backscattered electron (BSE) image (a) of a rosette in the sample cooled at $0.2^{\circ} \mathrm{C} / \mathrm{min}$ and EDS maps of Si, Cu and Fe (respectively b, c and d images). The localization of the different zones for TEM analysis, EBSD analysis and 3D reconstruction are shown in the BSE image.
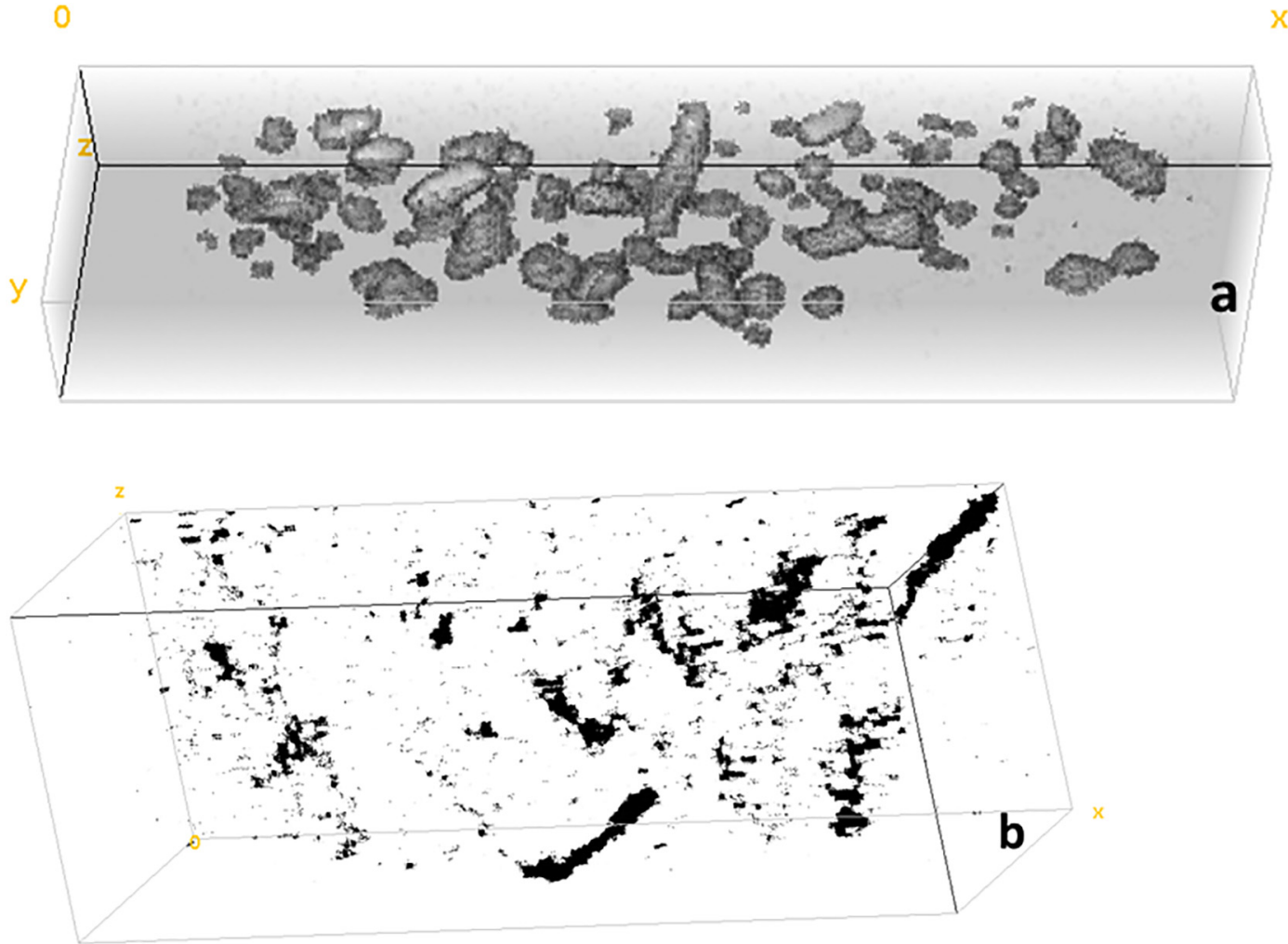

Fig. 8. 3D reconstruction of the silicon rich (a) and iron rich (b) areas in the rosette. The nominal size of the reconstruction box was $5 \times 10 \times 38 \mu m^{3}$ with slices $50 \mathrm{~nm}$ thick. The actual thickness of the slices was $63 \mathrm{~nm}$. 


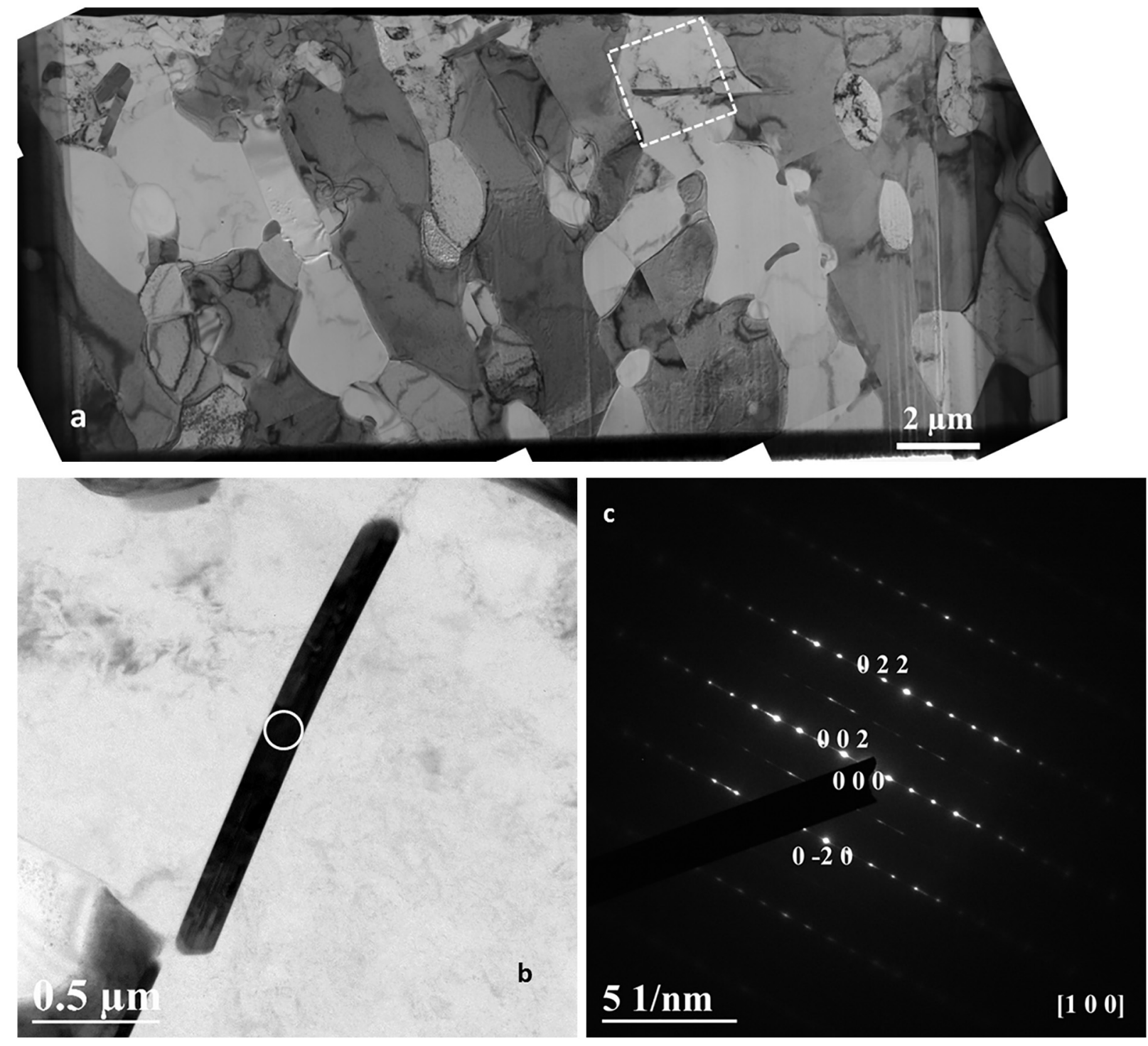

d

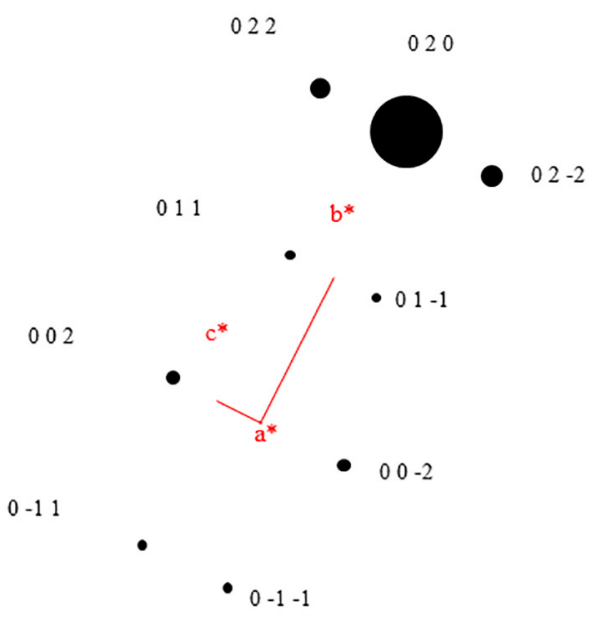

$0-22$

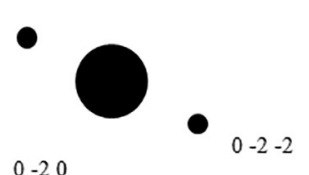




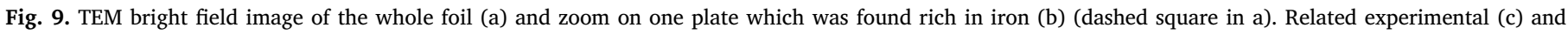

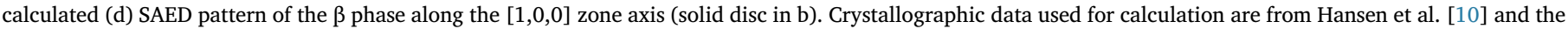
reconstruction was performed with CaRIne software [11].

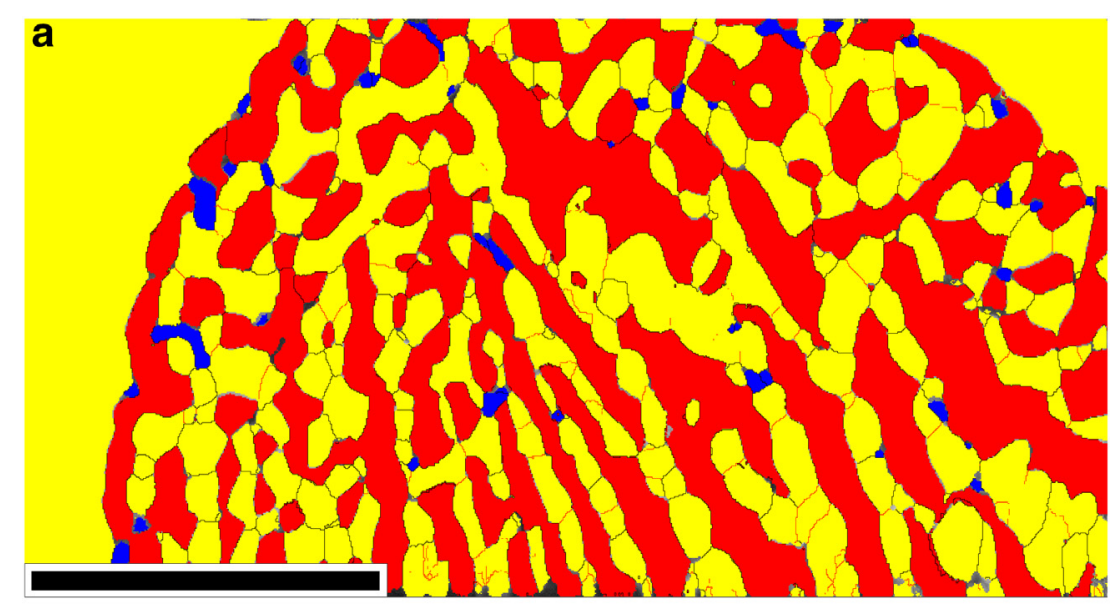

Fig. 10. Map of the phases that could be indexed with EBSDEDS analysis: (Al) in yellow, $\mathrm{Al}_{2} \mathrm{Cu}$ in red and silicon in blue (a). Phase and grain boundaries (misorientation higher than $10^{\circ}$ ) are indicated by dark lines and sub-grain boundaries (misorientation between 2 and $10^{\circ}$ ) for (Al) by yellow lines. (b): Image obtained by superimposition of band contrast and iron $\mathrm{K} \alpha$ (in red) maps. Band contrast (from black to white) corresponds to the quality of the diffraction pattern. The scale bar represents $20 \mu \mathrm{m}$. (For interpretation of the references to colour in this figure legend, the reader is referred to the web version of this article.)

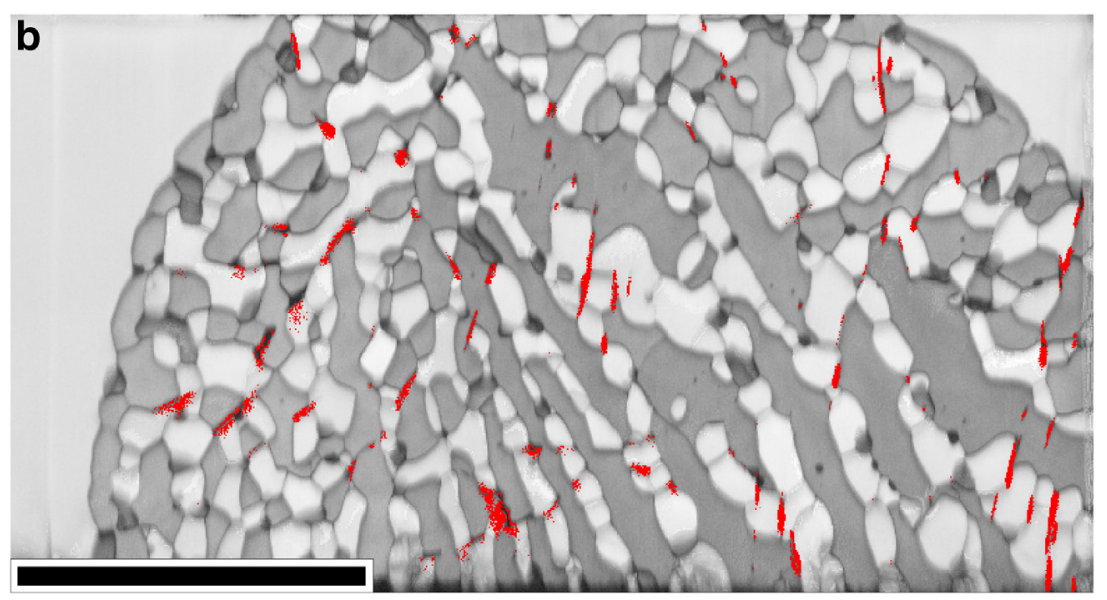

experimental plane distances and angles related to the diffracted spots of the diffraction pattern with literature values [10].

A foil labelled "EBSD" in Fig. 7 a was extracted using FIB for further analysis of phases and their orientation by EBSD. The phase mapping is seen in Fig. 10 a, with (Al) in yellow, $\mathrm{Al}_{2} \mathrm{Cu}$ in red and silicon in blue. Crystallographic data used for phase identification are: $\mathrm{i})(\mathrm{Al})$, space group $\mathrm{Fm} \overline{3} \mathrm{~m}$ with $\mathrm{a}=4.050 \AA$; ii) $\mathrm{Al}_{2} \mathrm{Cu}$, space group $\mathrm{I} / \mathrm{mcm}$ with $\mathrm{a}=6.067 \AA, \mathrm{c}=4.877 \AA$; and ii) $\mathrm{Si}$, space group $\mathrm{Fd} \overline{3} \mathrm{~m}$ with $\mathrm{a}=5.43 \AA$. As a matter of fact, the beta phase was not indexed which may be due to the small size of the precipitates as seen in Fig. 9. Instead, a network of thin dark lines is observed to divide the (Al) phase in blocks. A few of these dark lines are also present in the $\mathrm{Al}_{2} \mathrm{Cu}$ phase. It is noteworthy that the partitioning of the (Al) phase by the network of dark lines appears quite regular.

This network can be partly revealed by superimposing iron Ka map and band contrast image (Fig. $10 \mathrm{~b}$ ). It is thus seen that the beta plates correspond to many of the thin elongated areas that could not be in dexed (Fig. 10 a), though some dark lines or areas remain which are probably sub grain boundaries. The map in Fig. $10 \mathrm{~b}$ is consistent with TEM observation where $\beta$ phase was found in $(\mathrm{Al})$ matrix or at boundary between ( $\mathrm{Al}$ ) and $\mathrm{Al}_{2} \mathrm{Cu}$. This observation is illustrated in the STEM high angle annular dark field (HAADF) micrograph in Fig. 11 a where the $\mathrm{Al}_{2} \mathrm{Cu}$ phase appears light grey (see the EDS map of $\mathrm{Cu}$ in Fig. $11 \mathrm{~b}$ ) and the $\beta$ phase dark grey (see the EDS map of Fe in Fig. 11 c). (Al) and Si precipitates appear both in dark contrast but the last ones can be distinguished with the silicon EDS map (Fig. $11 \mathrm{~d}$ ).

The orientation variations of the different phases have been examined in order to give some insight on the solidification mechanism. The (Al) phase is first examined in Fig. 12, which represents a mapping of the misorientation with respect to the matrix grain (deep blue) where a reference point was selected (red disc at the top left of the map). This mapping reveals a progressive increase of the misorientation from the periphery toward the centre of the rosette. This suggests solidification of (Al) started from the surrounding matrix followed by quite a con tinuous change in orientation of the (Al) grain though some highly misoriented areas (in orange) are also seen from place to place. As clearly evidenced by the pole figures, the increasing misorientation corresponds to a continuous rotation around one single [100] direction which is stressed with the light grey regions superimposed to the pole figures. This rotation axis is identified with a dashed circle in the $\{100\}$ figure. What can also be seen in comparing Figs. 10 and 12 is that the local changes in orientation of the (Al) phase are closely related to the presence of $\beta$ plates and possibly of Si precipitates as well. In other words, the blocks defined in the (Al) phase by the network of thin dark lines seen in Fig. 10 a all show little internal misorientation while neighbouring blocks are slightly misoriented between each other.

The pole figures and angular deviation from a defined orientation for the Si precipitates are shown in Fig. 13. Silicon precipitates appear much as randomly oriented. This implies they are not interconnected as was suggested by the 3D reconstruction in Fig. 8 a. A few of the Si precipitates appear with two crystallographic orientations (different colours corresponding to twinning).

A similar analysis of crystal orientation has been conducted on the 

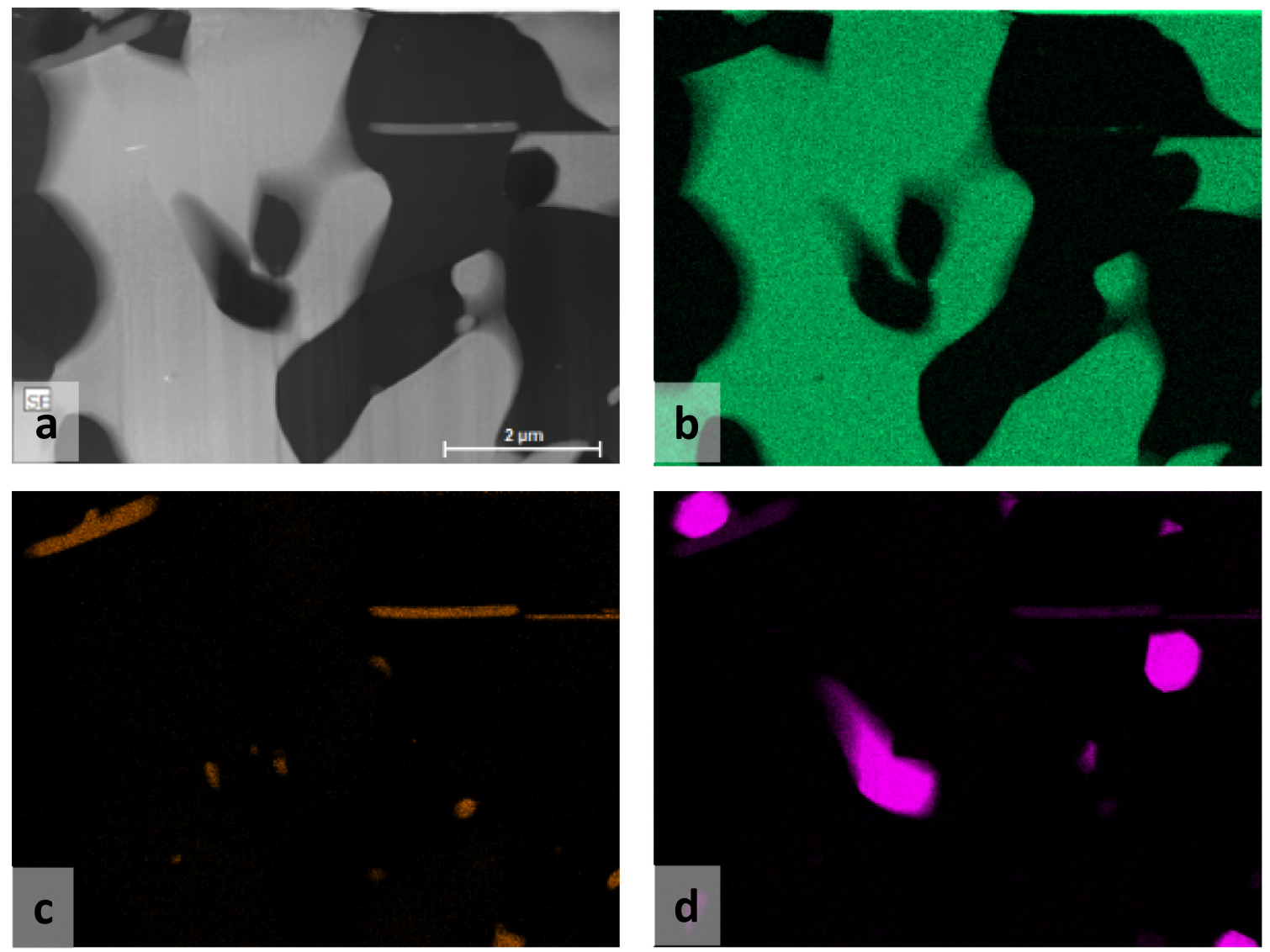

Fig. 11. STEM - HAADF micrograph (a), and STEM - EDS maps of copper (b), iron (c) and silicon (d) showing the positioning of $\beta$ and silicon precipitates with respect to the majority phases $\mathrm{Al}_{2} \mathrm{Cu}$ and (Al).

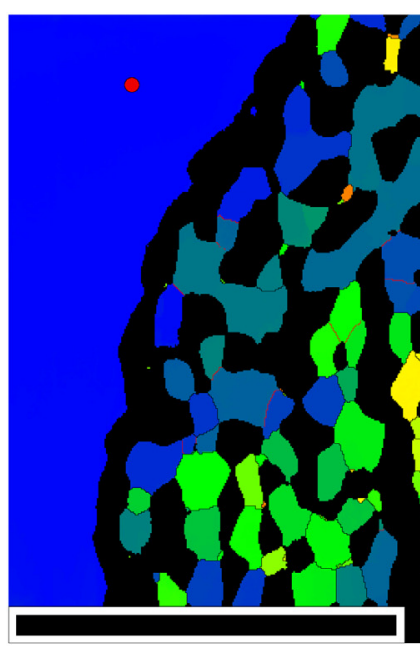

$\{100\}$
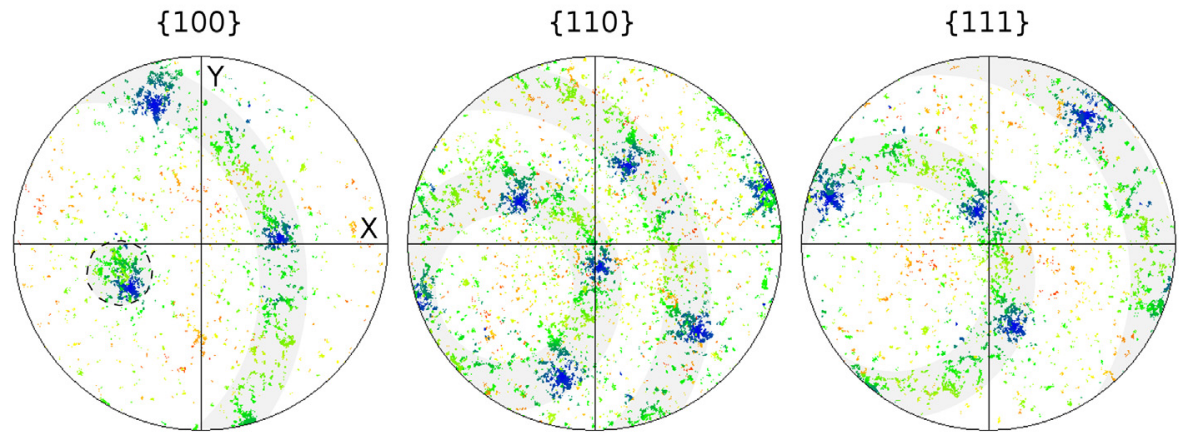

Fig. 12. Map of angular deviation $\left(0^{\circ}-60^{\circ}\right)$ from a defined orientation for the $(\mathrm{Al})$ phase in the rosette. The reference location is located in the outer (Al) matrix and marked with a red disc at the top left of the map. The corresponding pole figures of (Al) phase are shown in the lower row and indicate a rotation of the grains around a 100 pole as indicated by grey shading. The scale bar represents $20 \mu \mathrm{m}$. (For interpretation of the references to colour in this figure legend, the reader is referred to the web version of this article.) 

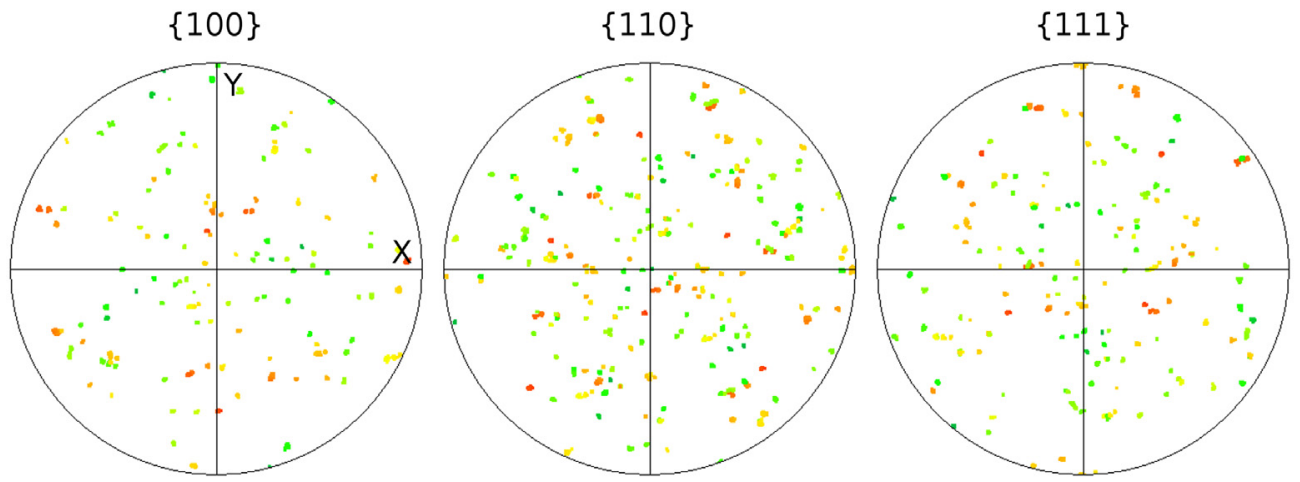

Fig. 13. Pole figures and angular deviation from a defined orientation for the Si precipitates. The colour from blue to red shows the change in orientation (between 0 and $60^{\circ}$ ) of the Si precipitates with respect to the orientation of the (Al) matrix out of the rosette (the reference point is the blue circle at the top left of the image). The scale bar represents $20 \mu \mathrm{m}$. (For interpretation of the references to colour in this figure legend, the reader is referred to the web version of this article.)

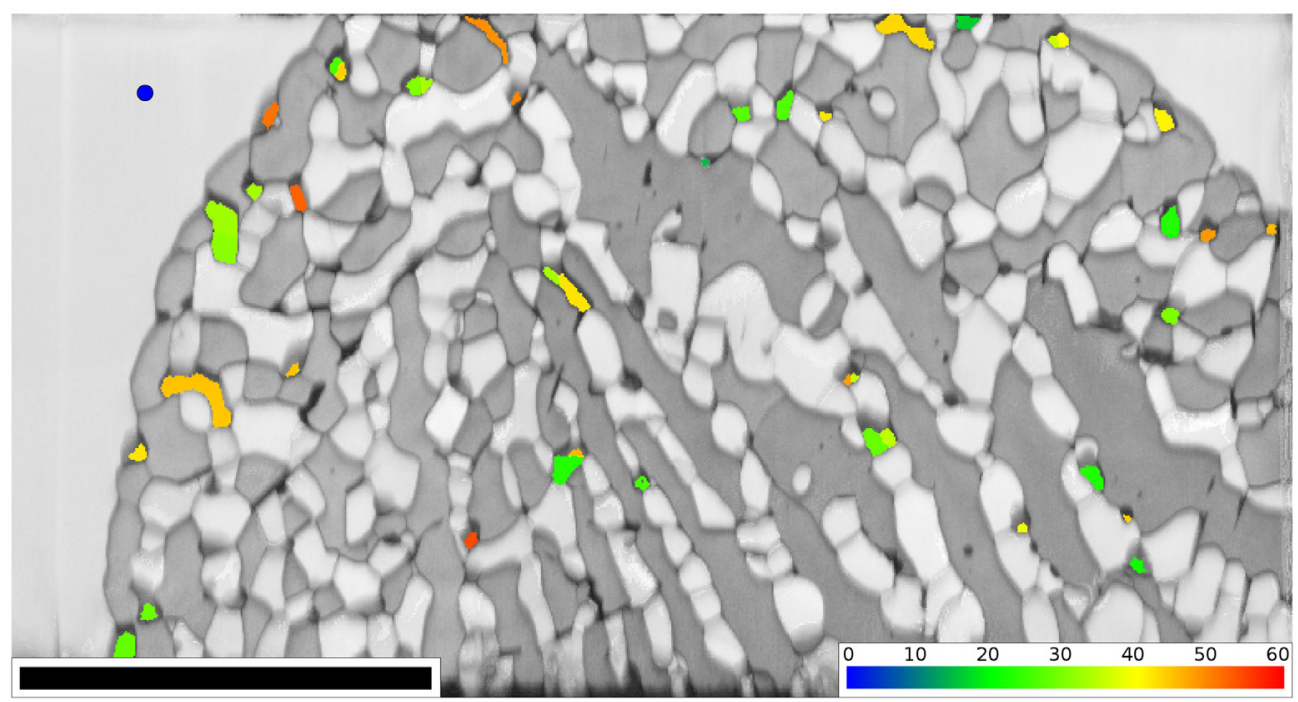

$\mathrm{Al}_{2} \mathrm{Cu}$ phase which is presented in Fig. 14. Two grains could be iden tified which correspond to well separated orientations on the pole fig ures and also to well defined regions on the image. The regions have been separated with an interrupted curve in Fig. 14. For each grain a continuous misorientation is observed which spreads over as much as $60^{\circ}$. It appeared convenient to define two reference points, one for each grain, which are shown as red discs on the bottom right of the map.

The stereographic projections for different poles are shown in Fig. 15 independently for both grains. It appears that the misorientation in each grain corresponds to a continuous rotation around a fixed [210] direction. This rotation axis is well distinct for each grain and is shown with a circle in each of the $\{210\}$ projections. Concerning the or ientation relationship between the two grains it is not clear if it consists in a rotation (circa $90^{\circ}$ around the image normal) or if it is a twin re lation.

Further, the orientation relation between $\mathrm{Al}_{2} \mathrm{Cu}$ and (Al) phases is quite difficult to establish since these crystals continuously rotate across the rosette. In the literature and for a $\mathrm{Al}-\mathrm{Cu}$ alloy rosette, Kim and Cantor [12] have noticed a superposition of [001] $]_{\mathrm{Al}}$ and [113] $]_{\mathrm{Al} 2 \mathrm{Cu}}$. For a slowly grown (Al)/ $\mathrm{Al}_{2} \mathrm{Cu}$ eutectic, Kraft [13] proposed the following phase juxtaposition which was later accepted by other authors [14]: Interface $/ /\{111\}_{(\mathrm{Al})} / /\{211\}_{\mathrm{Al} 2 \mathrm{Cu}}$ with $\langle 101\rangle_{(\mathrm{Al})} / /\langle 120\rangle_{\mathrm{Al} 2 \mathrm{Cu}}$.

This was confirmed by Davies and Hellawell [15] who wrote them as:

Interface $/ /\{111\}_{(\mathrm{Al})} / /(2 \overline{1} 1)_{\mathrm{Al} 2 \mathrm{Cu}}$ with $\langle 110\rangle_{(\mathrm{Al})} / /[210]_{\mathrm{Al} 2 \mathrm{Cu}}$

The latter authors however observed orientations differing from those reported by Kraft in that the $\{201\}_{(\mathrm{Al})}$ was almost parallel to $(110)_{\mathrm{Al} 2 \mathrm{Cu}}$ and $\{111\}_{(\mathrm{Al})}$ parallel to $(012)_{\mathrm{Al} 2 \mathrm{Cu}}$. Also, they could de monstrate that axes and directions of rotation change progressively with the phase appearing to follow one another. Lawson et al. [16] observed the following orientations:

$$
\begin{aligned}
& \text { Growth direction } / /[100]_{\mathrm{Al} 2 \mathrm{Cu}} / /\langle 310\rangle_{(\mathrm{Al})} \\
& \text { Interface } / /(001)_{\mathrm{Al} 2 \mathrm{Cu}} / /\{113\}_{(\mathrm{Al})}
\end{aligned}
$$

These authors noticed an approximate coincidence of $(211)_{\mathrm{Al} 2 \mathrm{Cu}}$ and $(111)_{(\mathrm{Al})}$ on the stereograms but stressed that the above planes are far from those reported by Kraft. To sum up, it appears that any of the orientation relationships observed in the literature could be evidenced from the information in Figs. 12 and 14. Further, since the rotations of the (Al) and $\mathrm{Al}_{2} \mathrm{Cu}$ phases do not seem to be correlated, it may be ar gued that $(\mathrm{Al})$ and $\mathrm{Al}_{2} \mathrm{Cu}$ could grow side by side during solidification of the rosette without consideration to their respective crystallographic orientation.

\section{Discussion}

Rosettes have been already reported in a number of works, e.g. in partly remelted melt spun $\mathrm{Al}-\mathrm{Cu}$ ribbons [12] and in direct chill (DC) casting of Al Fe Si [17] and Al Fe Mn Si [18] alloys. Rosettes have also been observed in materials reheated for solution treatment [19]. The very fine multiphase structure was related to solidification under cooling of isolated liquid droplets by Kim and Cantor [12], and this has been confirmed by DTA on an $\mathrm{Al} \mathrm{Cu} \mathrm{Mg} \mathrm{Si} \mathrm{alloy} \mathrm{[7].} \mathrm{In} \mathrm{this} \mathrm{latter} \mathrm{alloy}$ as well as in $\mathrm{Al} \mathrm{Fe} \mathrm{Si} \mathrm{alloys} \mathrm{[8,9],} \mathrm{it} \mathrm{was} \mathrm{noticed} \mathrm{that} \mathrm{the} \mathrm{number} \mathrm{of}$ rosettes increased with cooling rate. That the present results show an opposite trend is guessed to be due to the very large amount of eutectic in the present alloy which leads to isolation of liquid pools only when the structure has enough time for coarsening during solidification.

A particular feature of rosettes is that estimates of their composition have shown they are enriched in solutes with respect to the stable 

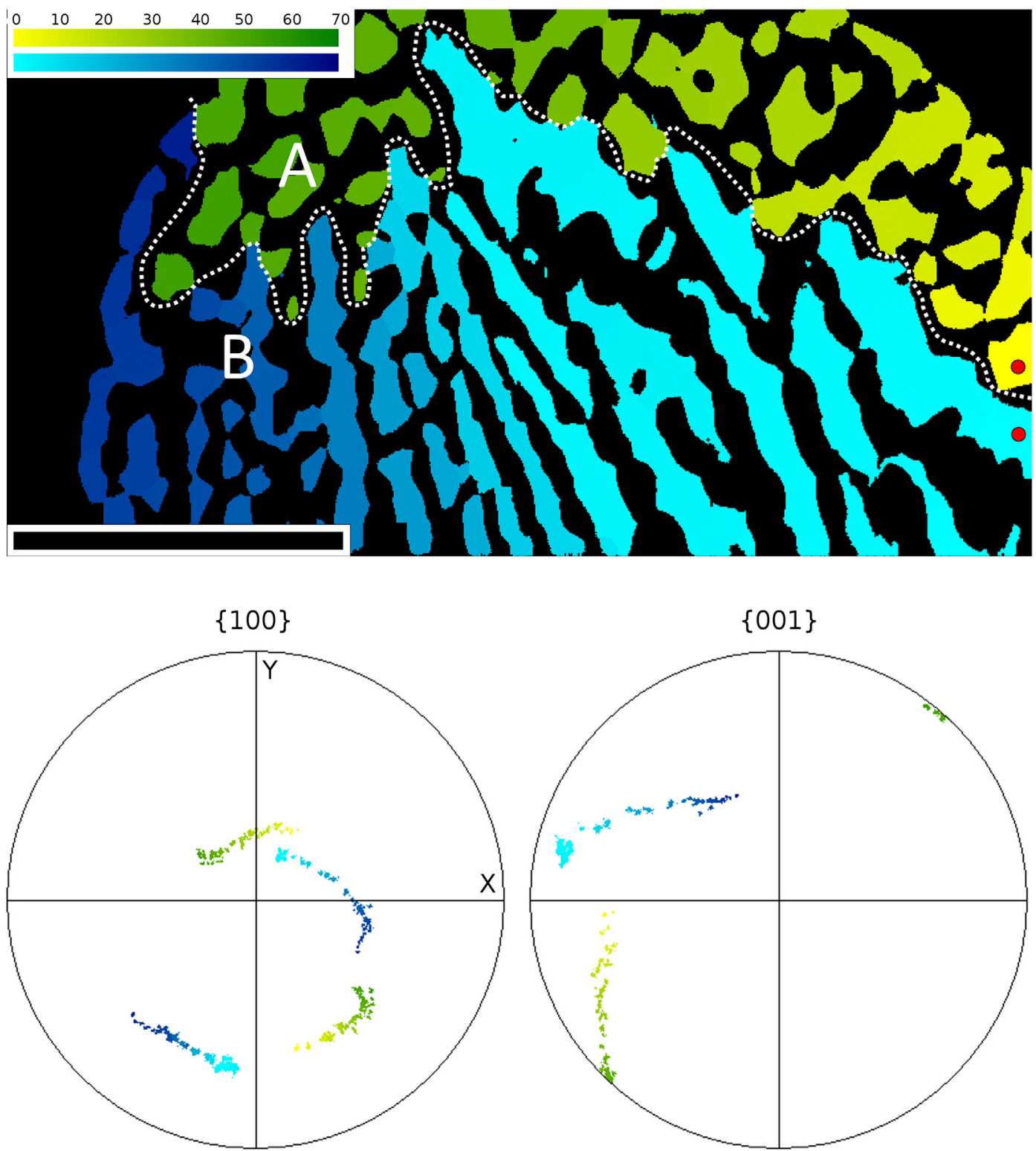

Fig. 14. Map of angular deviation from a defined orientation of the two separate regions ( $\mathrm{A}$ and $\mathrm{B}$ ) of $\mathrm{Al}_{2} \mathrm{Cu}$ phase. $\mathrm{A}$ reference point for each region is indicated as a red disc on the bottom right side. The colour code is identical for the map and for pole figures, yellow to green for region A and light to dark blue for region B. The scale bar represents $20 \mu \mathrm{m}$. (For interpretation of the references to colour in this figure legend, the reader is referred to the web version of this article.)

eutectic composition [7,18]. This off equilibrium enrichment could possibly explain the observation that melting occurred at temperature lower than the stable eutectic during heat treatment $[20,21]$.

In the interdendritic areas (see Fig. 5), the eutectic is irregular in the same way as the four phase $\mathrm{Al} / \mathrm{Cu} / \mathrm{Ag} / \mathrm{Mg}$ eutectic studied by direc tional solidification by Bin Zhou and Froyen [22]. By contrast, in the rosettes, the distribution of the four phases appears quite regular as was the case for the directionally solidified $\mathrm{Pb} / \mathrm{Sn} / \mathrm{Cd} / \mathrm{Zn}$ four phase eu tectic investigated by Fisher and Kurz [23]. It is of further interest to note that the $\beta$ phase is here perpendicular to the main direction of the (Al) and $\mathrm{Al}_{2} \mathrm{Cu}$ phases, acting in disrupting their growth. Such a feature was also characteristic of one of the minor phases in the four phase eutectic studied by Fisher and Kurz. This distinct "lattice work" ap pearance was assumed to allow minimizing interfacial area together with avoiding interferences in the diffusion fields [23].

\section{Conclusions}

DTA analysis of a $\mathrm{Al} \mathrm{Cu} \mathrm{Fe} \mathrm{Si} \mathrm{alloy} \mathrm{revealed} \mathrm{a} \mathrm{multiple} \mathrm{peak} \mathrm{at} \mathrm{the}$ end of solidification that could be associated with independent solidi fication of areas isolated from the interdendritic zones because of coalescence of the (Al) dendrites. Within these areas, a very fine four phase eutectic with a so called rosette like appearance was observed. Contrary to the four phase eutectic in the interdendritic zones, the eutectic in the rosettes shows a quite regular space distribution of the four phases, i.e. this is one of the very few regular four phase eutectics reported in the literature.

\section{Contributions}

D. Oquab and C. Josse performed the FIB milling and 3D re construction, A. Pugliara has carried out TEM investigation, A. Proietti and B. Viguier analysed the grain and phase orientations, J. Lacaze, S. Steinbach and D. Ferdian carried out DTA and optical microscopy 


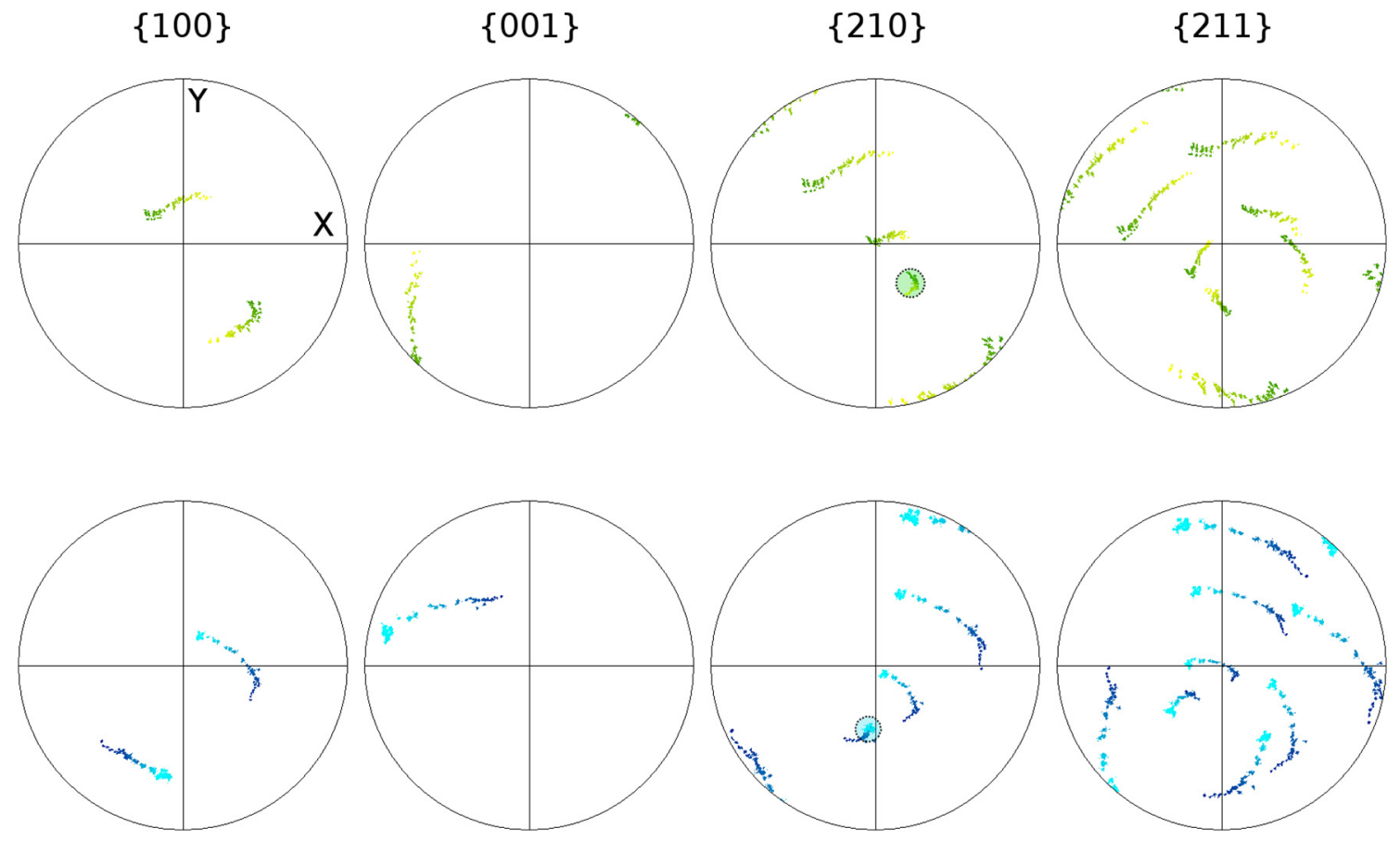

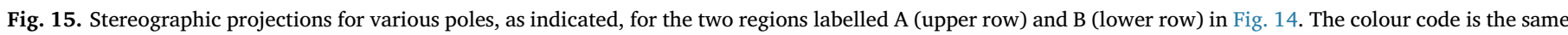
as in Fig. 14. (For interpretation of the references to color in this figure legend, the reader is referred to the web version of this article.)

analyses as well as the literature review. All co authors contributed to writing of the paper and have approved the present submission.

\section{Data availability}

The raw data are available upon request to the corresponding au thor.

\section{Declaration of competing interest}

None.

\section{Acknowledgments}

Part of this work was conducted within the ESA MAP programme MICAST, contract 14347/01/NL/SH. The sample material was kindly provided by Hydro Aluminium Deutschland GmbH, Bonn, Germany. Thanks are due to A. Lejri for the nice metallographic work he per formed during his 4 week licence internship at the CIRIMAT laboratory.

\section{References}

[1] S. Steinbach, et al., Investigation of the effect of fluid flow on microstructure evolution in Al-Si-Fe alloys: The MICAST project, Proceedings of the 5th Decennial International Conference on Solidification Processing, Old Windsor, July 2017, pp. $267-271$.

[2] L.F. Mondolfo, Aluminium Alloys, Structure and Properties, Butterworths, London, 1976.

[3] L. Backerud, G. Chai, J. Tamminen, Solidification Characteristics of Aluminum Alloys, vol. 2, AFS/Skanaluminium, Des Plaines, Illinois, 1990.

[4] N.A. Belov, D.G. Eskin, A.A. Aksenov, Multicomponent Phase Diagrams: Applications for Commercial Aluminum Alloys, Elsevier, Oxford, 2005.

[5] J.O. Andersson, T. Helander, L. Höglund, P.F. Shi, B. Sundman, Thermo-Calc and DICTRA, computational tools for materials science, Calphad 26 (2002) 273-312.
[6] Thermo-Calc Software TCAL aluminum-alloys database version 2

[7] J. Lacaze, G. Lesoult, I. Ansara, Rosettes in Al-Cu-Mg-Si aluminium alloys, Proc. ICAA-5, Mater. Sci. Forum 217-222 (1996) 171-176.

[8] D. Ferdian, Y. Thebault, A. Freulon, J. Lacaze, Characterization of rosettes formation in an Aluminum - Silicon alloy, Int. J. Cast Met. Res. 28 (2015) 290-294.

[9] D. Ferdian, D. Oquab, J. Lacaze, 3D characterisation of a rosette in an aluminumsilicon alloys, Proceedings of the 5th Decennial International Conference on Solidification Processing, Old Windsor, July 2017, pp. 410-413.

[10] V. Hansen, B. Hauback, M. Sundberg, C. Rømming, J. Gjønnesa, $\beta-\mathrm{Al}_{4.5} \mathrm{FeSi}$ : a combined synchrotron powder diffraction, electron diffraction, high-resolution electron microscopy and single-crystal X-ray diffraction study of a faulted structure, Acta Crystallogr. B B54 (1998) 351-357.

[11] C. Boudias, D. Monceau, CaRIne crystallography 3.1 (c) 1989-2019, http://carine crystallography.pagesperso-orange.fr.

[12] W.T. Kim, B. Cantor, Heterogeneous nucleation of $\mathrm{Al}_{2} \mathrm{Cu}$ in $\mathrm{Al}-\mathrm{Cu}$ eutectic liquic droplets embedded in an Al matrix, Acta Metall. Mater. 42 (1994) 3045-3053.

[13] R.W. Kraft, Crystallography of equilibrium phase interfaces in $\mathrm{Al}_{-} \mathrm{CuAl}_{2}$ eutectic alloys, Trans. Metall. Soc. AIME 224 (1962) 65-75.

[14] G. Garmong, C.G. Rhodes, Interfacial structure of $\mathrm{Al}_{-} \mathrm{Al}_{2} \mathrm{Cu}$ eutectic composites, Acta Metall. 22 (1974) 1373-1382.

[15] I.G. Davies, A. Hellawell, The structure of directionally frozen $\mathrm{Al}^{-\mathrm{CuAl}_{2}}$ eutectic alloy, Philos. Mag. 19 (1969) 1285-1297.

[16] W.H.S. Lawson, H.W. Kerr, M.H. Lewis, Cellular morphologies in rapidly solidified $\mathrm{Al}-\mathrm{Al}_{2} \mathrm{Cu}$ and Al-Al3Ni eutectic alloys, J. Cryst. Growth 12 (1972) 209-216.

[17] P. Liu, T. Thorvaldsson, G. Dunlop, Formation of intermetallic compounds during solidification of dilute Al-Fe-Si alloys, Mater. Sci. Technol. 2 (1986) 1009-1018.

[18] D.T.L. Alexander, A.L. Greer, Formation of eutectic intermetallic rosettes by entrapment of liquid droplets during cellular columnar growth, Acta Mater. 52 (2004) 5853-5861.

[19] P.N. Anyalebechi, J. Hogarth, Effect of supereutectic homogenization on incidence of porosity in aluminum alloy 2014 ingot, Metall. Mater. Trans. B Process Metall. Mater. Process. Sci. 25 (1994) 111-122.

[20] J.E. Hatch, Aluminum Properties and Physical Metallurgy, ASM International, 1984.

[21] J.R. Davis, Aluminum and Aluminum Alloys, ASM International, 1993.

[22] L. Bin Zhou, Froyen, Microstructure development in Al-Cu-Ag-Mg alloy, IOP Conf. Series: Mater. Sci. Eng. 27 (2012) (012031).

[23] D.J. Fisher, W. Kurz, Novel morphology of $\mathrm{Pb} / \mathrm{Sn} / \mathrm{Cd} / \mathrm{Zn}$ quaternary eutectic, Metall. Trans. 5 (1974) 1508-1510. 